\title{
The role of attitude, subjective norm, and perceived behavioral control (PBC) of mothers on teaching toothbrushing to preschool children - based on the Theory of Planned
} Behavior: a cross-sectional study

\author{
R. DARMAWAN SETIJANTO ${ }^{1, A-G}$, TAUFAN BRAMANTORO ${ }^{1, A-G}$, \\ ORCID ID: 0000-0003-0719-4189 \\ RETNO PALUPI I, B, F, ATIKA HANANI I, A, B, E, F \\ ${ }^{1}$ Departement of Dental Public Health, Faculty of Dental Medicine, Universitas Airlangga, Surabaya, Indonesia \\ ${ }^{2}$ Graduate Student, Faculty of Dental Medicine, Universitas Airlangga, Surabaya, Indonesia
}

A - Study Design, B - Data Collection, C - Statistical Analysis, D - Data Interpretation, E - Manuscript Preparation, F - Literature Search, G - Funds Collection

Summary Background. Indonesia has reported high prevalence and severity of early childhood caries (ECC). This is at $90 \%$ at age 3-5 years with higher mean of decay extraction or filling of teeth (def-t). Preschool children are one of the most vulnerable groups to dental and oral disease because they generally still not have proper behavior with regard to maintaining their oral health. Parental care is an important factor as it serves as the basis of the formation of behaviors that support or do not support childhood oral hygiene. One well-validated theory commonly used to test human attitudes and behaviors is the Theory of Planned Behavior.

Objectives. Based on the Theory of Planned Behavior, to describe the behavior of mothers on teaching toothbrushing to preschool children.

Material and methods. We undertook a cross-sectional analytic study with sample size 218 of mothers of kindergarten children in Surabaya. We obtained our data by giving a questionnaire to mothers that consists of 35 semi open ended and closed ended questions. Results. The variables of Theory of Planned Behavior which showed significant effect on intention to act were attitude and PBC with $p$-value $<0.005$. Subsequently, attitude, subjective norms, and PBC were tested together to measure the influence to intention - which resulted in a R2 of 0.37 .

Conclusions. Attitudes and PBC are the most dominant factors in improving the intentions and behavior of mothers towards teaching effective toothbrushing practices to their children.

Key words: dental caries, child, preschool, mothers, behavior, behavioral research.

Setijanto RD, Bramantoro T, Palupi R, Hanani A. The role of attitude, subjective norm, and perceived behavioral control (PBC) of mothers on teaching toothbrushing to preschool children - based on the Theory of Planned Behavior: a cross-sectional study. Fam Med Prim Care Rev 2019; 21(1): 53-57, doi: https://doi.org/10.5114/fmpcr.2019.82974.

\section{Background}

Dental caries are one of the most common dental health problems in the Indonesian community. The 2013 Basic Health Research (RISKESDAS) report stated that the average prevalence of Indonesian dental and oral problems is $25.9 \%$, whereas the average caries index is $4.6 \%$. Dental caries not only occured in adults, but also in children. Indeed, childhood dental caries are the most complained of dental health problems. The prevalence of caries in preschool children (aged 3-5 years) in Indonesia is reported to be $90.5 \%$ in urban areas and $95.9 \%$ in rural areas [1].

Early Childhood Caries (ECC) continues to be a worldwide pandemic disease. The prevalence of affected children aged 3-5 years old varies to continent and country. Cambodia and Indonesia have reported a high prevalence and severity of ECC, which reaches a figure of $90 \%$ at aged 3-5 years old - with a higher mean def-t.

Diseases and abnormalities of teeth in school-aged children are one of the interferences of children growth and development process. The most common dental health problem in children is dental caries. Dental caries is an infectious disease that damages tooth structure. The process occurs because of a number of factors in the mouth that interact with each other.
Alpers classifies three main factors: teeth, microorganisms, substrates, and one additional factor, that is time. In addition to the main factors in the mouth, there are external predisposing factors such as age, sex, socioeconomic status, oral hygiene, and cariogenic foods [2]. Dental health education should be introduced as early as possible to the child, so they understand how to correctly maintain healthy teeth and mouth. Preschool aged children are one of the most vulnerable groups to dental and oral diseases due to lack of behavior or habit that support dental health [3]. In this case, the role of parents is very significant in maintaining the health and hygiene of children's teeth and mouth. Attitudes and behaviors of parents who are the closest to the child with regard to health care give a very significant effect on the attitude and behavior of their offspring. A person who has a high level of education will have good knowledge and attitude about health, so that it will affect his/her drive to healthy lifestyles [4].

The Indonesian Dentists Association (PDGI) states that child dental hygiene involves interaction between children, parents and dentists. Herein, the influence of parents is instrumental in shaping the behavior of children. Attitudes and behavior of parents, especially the mother (who is usually the closest to the child in maintaining dental health), have a significant effect on the behavior of children [5]. Dental-wise, a child should get 
serious attention from the parents even though they still have deciduous teeth. This is because the condition of the deciduous teeth will determine the growth of the child's permanent teeth. However, many parents assume that deciduous teeth are temporary and will be replaced by permanent teeth, so they often assume that damage to the deciduous tooth is not a problem.

In the parenting decision model, Hoover-Dempsey and Sandler identified role construct as a fundamental variable that influences parental decision. Role construct relates to how parental accountability or responsibility perceives themselves in relation to their child's behavior. Hoover-Dempsey and Sandler proposed that parental construct about the role of parents are strongly influenced by the definition of parent roles and their beliefs about child development, child nurture, and what parents expect [6]. The role of parents is crucial as the basis for the formation of supportive or not supportive behaviors of child oral hygiene [7]. While young children aged $4-5$ years depend mainly on adults on decisions about their health, parental actions can impact on behaviors shown by children and adolescents at a later stage in their lives when they are able to make their own decisions about their health [8]. One well-validated decision-making model commonly used to test attitudes and behavior is the Theory of Planned Behavior (TPB). TPB suggests that intentions affecting behavior are influenced by attitudes (assessment of behavior as something that is advantageous/disadvantageous), subjective norms (perceptions of social pressure to do or not to do a behavior) and perceived behavior control (PBC, perceived eases/difficulties to act a behavior), with $\mathrm{PBC}$ directly predicting a behavior. In TPB, past behavior is also often included as an additional predictor of people's intentions and behaviors [9].

\section{Objectives}

The aim of this study was to predict using the theory of planned behavior, the behavior of mothers to teaching toothbrushing to preschool children. Based on the construction of Theory Planned Behavior, the better attitudes and subjective norms associated with involvement in behavior and the greater the perceived control, the more likely it is that a person will form an intention to behave. Finally, intentions are expected to lead to behavioral performance as long as people are actually able to do so, that is, where they have actual control over the behavior.

\section{Material and methods}

\section{Study design}

This study were performed via a protocol approved by the Health Research Ethical Clearance Commission Faculty of Dental Medicine, Universitas Airlangga, with ethical approval number: No. 109/HRECC.FODM/VII/2017. We used cross sectional design in this study.

\section{Participants}

The cross sectional study recruited a maternal group with the following inclusion criteria: biological parent of kindergarten children in Surabaya city. The sample used in this study was the mothers of kindergarten-aged children who were randomly determined from each region in the city of Surabaya: East, West, Central, North and South. The number of samples used in this study was 218. The sample characteristics are shown in Table 1. The study was conducted from June 2017 until July 2018. Before the conducted study, each participant was requested to complete a form of concent.

\section{Setting}

To collect the data, we asked participants to fill-in the questionnaire. This study uses a research instrument in the form of a questionnaire adapted from the guidelines for the preparation of TPB questionnaires by Ajzen. Questions were compiled based on TPB components, namely, actions, intentions, attitudes, subjective norms, and perceived control, with questions totaling 35. Likert data scales were applied to determine the behavior of mothers on how to teach tooth brushing to preschool. The questionnaire measures the effect of the theory construct about intention to improve oral hygiene behavior.

\section{Variables}

All the variables were measured consistently. Hence, the higher average score reflects more positive attitudes, positive subjective norms, and higher perceived behavior control toward oral health behaviors.

\section{Statistical analysis}

Data was analyzed by calculating Correlation and Linear Test Regression of components of planned behavior theory where the result of $p$-value less than 0.05 is considered as statistically significant.

\section{Results}

The result of participant characteristic data is shown in Table 1. Firstly, the mother's degree of formal education was classified into 2 categories: basic education (elementary school/ /junior high school/senior high school) which consisted of $69.73 \%$ of total sample, and higher education which reached $30.28 \%$ of total sample. Secondly, the employment status of the mother was categorized as working $(45.41 \%)$ or not working (54.59\%). Thirdly, the percentage of maternal income per month was classified into 3 categories: IDR $<1.000 .000$ (22,94\%), IDR $1.000 .000-3.000 .000$ (55.51\%) and IDR > 3.000.000 (21.56\%).

\begin{tabular}{|l|l|l|l|}
\hline Table 1. Sample characteristics \\
\hline Variables & Descriptions & \multicolumn{2}{|l|}{ Total } \\
\cline { 3 - 4 } & & $\begin{array}{l}\text { Number } \\
(n)\end{array}$ & $\%$ \\
\hline Education & $\begin{array}{l}\text { basic education } \\
\text { (elementary school/junior } \\
\text { high school/senior high } \\
\text { school) }\end{array}$ & 152 & 69.73 \\
\cline { 2 - 4 } & higher education & 66 & 30.28 \\
\hline Employment & not working & 119 & 54.59 \\
\cline { 2 - 4 } & working & 99 & 45.41 \\
\hline Salary & $<$ IDR 1.000.000 & 50 & 22.94 \\
\cline { 2 - 4 } & $\begin{array}{l}\text { IDR 1.000.000- } \\
\text {-IDR 3.000.000 }\end{array}$ & 121 & 55.51 \\
\cline { 2 - 4 } & $>$ IDR 3.000.000 & 47 & 21.56 \\
\hline
\end{tabular}

In Table 2, we analyzed the data using the Mann-Whitney test. The education variable toward the subjective norms had $p$-value $<0.05$, which means there was a difference in higher education and lower education to them. The education variable toward attitude, perceived behavior control, intention and behavior variables, however, showed $p$-value $>0.05$, which indicates that there was no difference in higher education and lower education to variables other than the subjective norms. Furthermore, the employment variable showed $p$-value $>0.05$ towards all components of the theory of planned behavior, hence, there was no difference between working and not working to the components of planned behavior theory. Lastly, the income variable showed $p$-value $>0.05$ towards all components of the theory of planned behavior, which means there was no difference between salary levels to the components of planned behavior theory. 


\begin{tabular}{|c|c|c|c|c|c|c|c|c|c|c|c|c|c|c|c|c|}
\hline \multicolumn{2}{|c|}{ Socio-demographic } & \multicolumn{3}{|c|}{$\begin{array}{l}\text { Attitude toward } \\
\text { behavior }\end{array}$} & \multicolumn{3}{|c|}{ Subjective norms } & \multicolumn{3}{|c|}{$\begin{array}{l}\text { Perceived behavior } \\
\text { control }\end{array}$} & \multicolumn{3}{|c|}{ Intention } & \multicolumn{3}{|c|}{ Behavior } \\
\hline & & Mean & SD & $p$ & Mean & SD & $p$ & Mean & SD & $p$ & Mean & SD & $p$ & Mean & SD & $p$ \\
\hline \multirow[t]{2}{*}{ Education } & high & 28 & 3.62 & \multirow[t]{2}{*}{0.446} & 55.48 & 20.377 & \multirow{2}{*}{0.016} & 26.36 & 4.23 & \multirow[t]{2}{*}{0.669} & 28.67 & 3.125 & \multirow[t]{2}{*}{0.43} & 4.36 & 0.922 & \multirow[t]{2}{*}{0.117} \\
\hline & low & 27.68 & 3.096 & & 62.88 & 19.978 & & 26.05 & 4.335 & & 28.14 & 3.143 & & 4.56 & 0.77 & \\
\hline \multirow{2}{*}{$\begin{array}{l}\text { Employ- } \\
\text { ment }\end{array}$} & not working & 27.76 & 2.951 & \multirow[t]{2}{*}{0.571} & 58.9 & 19.366 & \multirow{2}{*}{0.115} & 26.26 & 4.412 & \multirow[t]{2}{*}{0.372} & 28.54 & 2.81 & \multirow[t]{2}{*}{0.165} & 4.56 & 0.732 & \multirow[t]{2}{*}{0.441} \\
\hline & working & 27.79 & 3.609 & & 58.9 & 19.366 & & 26.01 & 4.171 & & 28.01 & 3.489 & & 4.42 & 0.916 & \\
\hline \multirow[t]{3}{*}{ Salary } & IDR $<1.000 .000$ & 27.9 & 2.306 & \multirow[t]{3}{*}{0.391} & 61.7 & 20.528 & \multirow{3}{*}{0.764} & 26.82 & 3.415 & \multirow[t]{3}{*}{0.615} & 28.12 & 3.075 & \multirow[t]{3}{*}{0.924} & 4.7 & 0.505 & \multirow[t]{3}{*}{0.168} \\
\hline & \begin{tabular}{|l|} 
IDR $1.000 .000-$ \\
- IDR 3.000.000
\end{tabular} & 27.5 & 3.795 & & 61.16 & 19.881 & & 25.82 & 4.592 & & 28.23 & 3.366 & & 4.49 & 0.857 & \\
\hline & IDR $>3.000 .000$ & 28.36 & 2.506 & & 58.17 & 21.526 & & 26.28 & 4.342 & & 28.66 & 2.59 & & 4.32 & 0.958 & \\
\hline
\end{tabular}

$p$-value significant at $<0.05$.

In the table above, the effect of higher education on attitude variables, PBC and intention had a higher mean compared with lower educational levels, while basic education to subjective norms and behavior variables showed a higher mean compared with higher education. Towards the attitude variable, being employed had higher mean compared with being unemployed, whereas unemployed participants toward PBC, intention and behavior variables had higher mean. Participants that had income IDR > 3.000.000 toward attitude and intentions had a higher mean compared to lower income earneers. The Spearman correlation of this study is shown in Table 3.

\begin{tabular}{|l|l|l|l|l|l|}
\hline \multicolumn{6}{|c|}{ Table 3. Correlation test of TPB components } \\
\hline & Attitude & $\begin{array}{l}\text { Subjective } \\
\text { norm }\end{array}$ & PBC & $\begin{array}{l}\text { Inten- } \\
\text { tion }\end{array}$ & $\begin{array}{l}\text { Behav- } \\
\text { ior }\end{array}$ \\
\hline Attitude & 1 & & & & \\
\hline $\begin{array}{l}\text { Subjective } \\
\text { norm }\end{array}$ & & 1 & & & \\
\hline PBC & & & 1 & & \\
\hline Intention & $0.478^{*}$ & 0.069 & $0.409^{*}$ & 1 & \\
\hline Behavior & & & $0.416^{*}$ & $0.399^{*}$ & 1 \\
\hline
\end{tabular}

$* p$-value significant at $<0.05$.

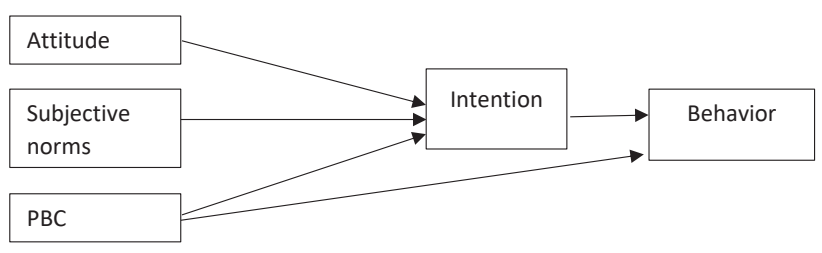

Figure 1. The hypothesis of relationship among TPB components

Based on Figure 1, we could see in Table 3 that the attitude variable had a significant relationship with the intention variable, with $p$-value $<0.05$ and correlation coefficient $(r) 0.478$. This means attitude had significant relationship with intention. In addition, the subjective norm had no significant relationship with intention - with $p$-value at 0.312 and correlation coefficient $(r)$ of 0.069 , which means the subjective norm had no significant relationship with intention. Perceived behavioral control had, however, a significant relationship with intention, with $p$-value $<0.05$ and correlation coefficient $(r) 0.409$. This implies that $\mathrm{PBC}$ had a significant relationship with the intention. Furthermore, intention had a significant relationship with behavior - with $p$-value $<0.05$ and correlation coefficient $(r) 0.399$, albeit intention had a less significant relationship with behavior. Subsequently, $\mathrm{PBC}$ had a significant relationship with behavior, with $p$-value $<0.05$ and correlation coefficient $(r) 0.416$. Thus, PBC had a significant relationship with behavior.

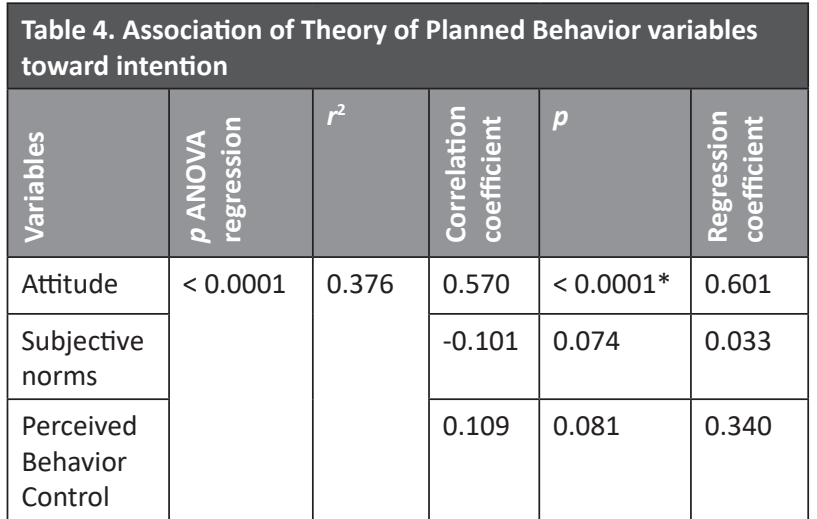

$* p$-value significant at $<0.05$.

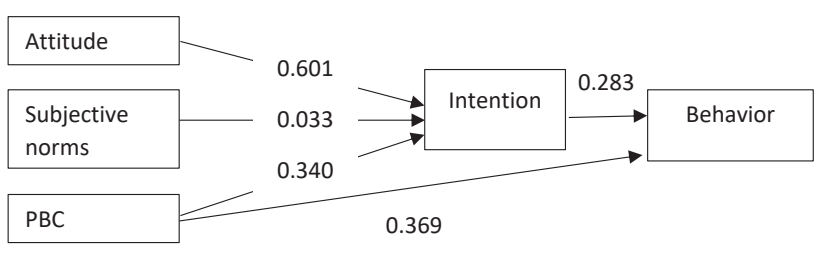

Figure 2. Linear regression test of TPB components

Figure 2 showed that among the variables, attitude had most significant relationship to intention (with $p<0.0001$ ).

\section{Discussion}

Based on the construction of the Theory of Planned Behavior, in this study, the most powerful variables affecting intention were attitude and perceived behavior control. In the above, correlation statistic test showed the result of attitude toward behavior. This being positive at 0.478 with $p$-value $<0.0001$. Hence, the attitude variable had a significant effect on intention. What is more, the result of the correlation coefficient on the PBC variable was positive $(0.409)$ with $p$-value $<0.0001$. Based on this, it could be concluded that there was a significant effect of PBC to intention.

The possibility of bias from the use of questionnaires in this study has been overcome through validity and reliability testing, so we assume that the results of this study do not provide biased results.

The results of the above analysis showed that there were two variables that had significant influence on intention. The higher the attitude (attitude toward behavior) and the PBC of a person, the higher the intention of the mother in teaching children to brush their teeth. In the context of families, children should not be regarded merely as passive care recipients in the daily routine of health measures, as they do play active roles 
in making healthy choices [10]. Mothers definitely contribute to healthy family activities. Thus, families, especially mothers, should promote the health of their children and their children's ability to develop a healthy lifestyle. The significant influence of the mother's attitudes toward the oral health of children can be attributed to the impact of their attitudes toward the behavior of their children [11]. This refers to the deep interactions between mother and child, and supports the mother's role as an important source of perception and acceptance of children to attitudes, values, and behaviors, especially during critical times in establishing attitudes and beliefs and shaping individual health behaviors [12].

Based on the results of the analysis, this study was considered successful enough to reveal the factors that affect the intention. The dominant factors influencing mother's behavior in teaching toothbrushing to children are factors that are purely derived from within oneself, namely: individual attitudes and individual self-control on the other hand, the results of this study indicate that external factors such as the influence of others (subjective norms) do not affect the participants [13].

The effect of the attitude variable on intention can explain the problem of overcoming tooth and mouth problems in children. Thus, due attention and supervision of parents (especially mothers) is required to control and support child in proper oral care activity. In this attitude variable, mother must hold the belief that by teaching effective tooth brushing to children, that child will be protected from dental and mouth disease [14].

Attitude is the reaction or response of a person to stimulation or to an object. Mothers have an important role in preventing caries disease in that they transmit habits and rituals. To be effective, they must have good knowledge about oral car and cary prevention. The overall attitude of mothers and attitudes toward their child's oral hygiene has been associated with caries occurrence and oral hygiene status, and a mother's positive attitude has been shown to result in increased teeth brushing, decreased caries lesions and better oral hygiene [13, 14]. Factors influencing attitudes include personal experience, socioeconomic status, mass media, knowledge and religion.

Knowledge or cognitive is a very important domain in shaping the action of someone (overt behavior) because knowledge is one predisposing factor of the formation of a whole attitude or total attitude based on the three components of the belief idea, the conception of an object and the tendency to act (tend to behave). According to [15], low knowledge will tend to be negative in determining attitudes and high knowledge will be positive in determining attitude. This result is in accordance with Skeie et al., where mothers with low levels of education tend to have a tooth attitude that not good.

There are several possible explanations for poor teeth attitudes in older people with low levels of education. The norms and attitudes of parents may be influenced by the norms of child care existing in their community and transmitted from one generation to another $[16,17]$. In parents with low levels of education, oral health may not be assessed positively and importantly [18]. Moreover, if economic constraints exist in daily life, good oral health habits may not be a parental priority. In addition, parents with low levels of education also often lack the skills to process certain health-related information and to interact with health institutions and professionals. This then leads to less positive attitudes [19]. In general, attitudinal levels of receiving, responding, respecting and being responsible is differentiated into positive and negative.

The influence of PBC variables are noticeable when the mother is faced with circumstances in which she must choose to teach her children to brush their teeth properly and correctly or not. As mentioned earlier, PBC is a level of perception of one's own ability to perform an action related to risks or constraints. $\mathrm{PBC}$ in the context of this study is related to the ability of the mother. The positive impacts if children are taught to brush their teeth properly go beyond possessing strong teeth and fresh breath, but the mouth is also clean enough from the germs and bacteria that cause dental and oral diseases and general health problems [14]. Thus, it is hoped that the mother is able to uphold the postive health-care of her children, especially in dental and oral practices, because mothers are considered role models in their child's health behavior in transferring acceptable values, norms and behaviors [20]. Therefore, parents, especially mothers, function as social models for children.

Dental caries is a disease that evolved through the biological interactions of acidic bacteria root complex, fermentable carbohydrates and host factors such as teeth and saliva [21]. For decades, species of acidogenic bacteria Streptococcus mutans have been considered the main causal agents of dental caries. This process occurs so slowly that most children and parents are unaware of and ignore the presence of dental plaques that can cause tartar so that many children have dental defects that are mostly dental caries, which is frightening to everyone, especially parents [15]

The absence of the influence of factors or subjective norm variable in this study can be explained from the context of the study subjects. The subjective norm is the influence of the environment or the people who are considered important to someone. In the context of the mother, the person who is predicted to have great influence in various ways is a husband's friend [12]. However, it turns out that in teaching toothbrushing in children, those closest people have no significant effect. When associated with the two other variables that affect intention, the results are not $s$ significant subjective norm variable to support the opinion that the behavior of the mother in teaching toothbrushing on the child is very dependent upon the thoughts and internal factors within the individual.

\section{Conclusions}

In Surabaya, when mothers teachs toothbrushing behaviors to their preschool-aged children, based on the Theory of Planned Behavior, such behavior is closely related to attitude and perceived behavior control variables. In the study it was found that the subjective norms variable is not related to the mother's behavior. In this study, although the mother's surrounding environment does not support the teaching of toothbrushing tochildren, mothers having positive attitudes and intention will teach toothbrushing to their children.

Source of funding: This work was funded from the authors' own resources.

Conflicts of interest: The authors declare no conflicts of interest.

\section{References}

1. Fitriani. Risk Factors of Early Childhood Caries (Case Study in Islamic Children School Pangeran Diponegoro) (Thesis). Semarang: Universitas Diponegoro; 2007.

2. Selwitz RH, Isamail Al, Pitts NB. Dental caries. Lancet 2007; 369(9555): 51-59.

3. Sondang P, Hamada T. Towards Healthy Teeth and Mouth, Prevention and Maintenance. Medan: Universitas Sumatera Utara; 2008; 28-30. 
4. Mustika Natamiharja L, Dwi NS. The relationship of education, knowledge and behavior of mother to tooth caries status. Dentika Dent J 2010; 15(1): 37.

5. Lina N, Kosasi I. Mother's behavior in prevention of dental disease child in Kelurahan Gang Buntu medan. Dentika Dent J 2010; 12(2): 133-139.

6. Hoover-Dempsey KV, Sandler HM. Why do parents become involved in their children's education? Rev Educ Res 1997: 67(1): 3-42.

7. Casamassimo PS, Fields Jr HW, McTigue DJ, et al. Pediatric dentistry: infancy through adolescence, 5/e. India: Elsevier; 2012.

8. Bennetts K, Borland R, Swerissen H. Sun protection behaviour of children and their parents at the beach. Psychol Health 1991: 5; 279-287.

9. Conner M, Armitage CJ. Extending the theory of planned behavior: a review and avenues for future research. J App/ Soc Psychol 1991: 8(28); 1429-1464.

10. Mutuli LA, Walingo M. Applicability of theory of planned behavior in understanding breastfeeding intention of postpartum women. Int J Multidiscip Res 2014; 2; 78-89.

11. Saied-Moallemi Z, Virtanen J, Ghofranipour F, et al. Influence of mothers' oral health knowledge and attitudes on their children's dental health. Eur Arch Paediatr Dent 2008; 9(2): 79-83.

12. Christensen P. The health-promoting family: a conceptual framework for future research. Soc Sci Med 2004; 59: 377-387.

13. Skeie MS, Riordan PJ, Klock KS, et al. Parental risk attitudes and cariesrelated behaviours among immigrant and western native children in Oslo. Community Dent Oral Epidemiol 2006; 34: 103-113.

14. Saied-Moallemi Z, Vehkalahti MM, Virtanen Jl, et al. Mothers as facilitators of preadolescents' oral self-care and oral health. Oral Health Prev Dent 2008; 6(4): 271-277.

15. Christensen LB, Twetman S, Sundby A. Oral health in children and adolescents with different socio-cultural and socioeconomic backgrounds. Acta Odontol Scand 2010; 68: 34-42.

16. Azwar S. Sikap Manusia, Teori Dan Pengukurannya. Yogyakarta: Pustaka Belajar; 2008: 85-90 (in Indonesian).

17. Skeie MS, Klock KS, Haugejorden O, et al. Tracking of parents attitudes to their childrens oral healthrelated behavior - Oslo, Norway, 2002-2004. Acta Odontol Scand 2010; 68: 49-56.

18. Skeie MS, Espelid I, Riordan PJ, et al. Caries increment in children aged 3-5 years in relation to parents dental attitudes: Oslo, Norway 2002 to 2004. Community Dent Oral Epidemiol 2008; 36: 441-450.

19. Sisson KL. Theoretical explanations for social inequalities in oral health. Community Dent Oral Epidemiol 2007; 35: 81-88.

20. Astrom AN, Kiwanuka SN. Examining intention to control preschool childrens sugar snacking: a study of carers in Uganda. Int J Paediatr Dent 2006; 16: 10-18.

21. Nourijelyani K, Yekaninejad MS, Eshraqhian MR, et al. The influence of mothers' lifestyle and health behavior on their children: an exploration for oral health. Iran Red Crescent Med J 2014; 16(2): e16051.

Tables: 4

Figures: 2

References: 21

Received: 11.07.2018

Reviewed: 9.08.2018

Accepted: 28.09.2018

Address for correspondence:

Taufan Bramantoro, DDS, MPH, PhD

Department of Dental Public Health

Faculty of Dental Medicine

Universitas Airlangga

Jl. Mayjend Prof Dr Moestopo 47

60132 Surabaya

Indonesia

Tel.: (+62 31) 5030255, 5020256

E-mail: taufan-b@fkg.unair.ac.id 